\title{
CZY POTRZEBNE SĄ ZMIANY W KONSTYTUCYJNEJ KARCIE PRAW?*
}

I. Trudno jest wypowiedzieć się na temat określony w tytule bez chociażby krótkiej refleksji nad aktualnością samej Konstytucji RP z 1997 r. Już jej preambuła nie pozostawia co do tego żadnych wątpliwości, że karta praw jest integralną częścią ustawy zasadniczej nie tylko w redakcyjnym, ale przede wszystkim w materialnym sensie. Stwierdza ona, że Konstytucja została ustanowiona ,jako prawa podstawowe dla państwa oparte na poszanowaniu wolności i sprawiedliwości, współdziałaniu władz, dialogu społecznym oraz na zasadzie pomocniczości umacniającej uprawnienia obywateli i ich wspólnot". Stosujący ją powinni czynić to z dbałością „o zachowanie przyrodzonej godności człowieka, jego prawa do wolności i obowiązku solidarności z innymi, a poszanowanie tych zasad mieli za niewzruszoną podstawę Rzeczypospolitej Polskiej”. Poświęcenie wolnościom, prawom i obowiązkom człowieka i obywatela obszernego rozdziału II Konstytucji, zaraz po unormowaniu zasad ustroju, świadczy o centralnym znaczeniu przypisanemu przez ustrojodawcę statusowi prawnemu jednostki.

II. Rok 1997 był przełomowym rokiem w historii polskiego ustawodawstwa konstytucyjnego. Wieńczył lata dyskusji, sporów i negocjacji kontraktem społecznym dla Polski w postaci nowej demokratycznej Konstytucji ${ }^{1}$. Pogłębiona refleksja w tej materii zaczęła się już w latach osiemdziesiątych, kiedy przewidywania końca ówczesnego ustroju zaczęły nabierać bardziej realnych, aczkolwiek ciagle jeszcze do końca niezdefiniowanych czasowo, perspektyw. Silną stroną tego procesu było osadzenie go od początku w kontekście dorobku nowoczesnego konstytucjonalizmu, czerpiącego z doświadczeń państw demokratycznych.

Nie ma podstaw, aby sądzić, że ów nowoczesny konstytucjonalizm, którego integralnym składnikiem sa prawa i wolności jednostki oparte na godności człowieka oraz zasadach wolności i niedyskryminacji, „zestarzał się” przez ostatnie 20 lat i przestał być adekwatny do określania ustroju państw demokratycznych. Co więcej, zasięg jego wpływów stale się powiększa. Konstytucje przyjmowane $\mathrm{w}$ ostatnich dziesięcioleciach $\mathrm{w}$ demokratycznych państwach

\footnotetext{
" Tekst ten jest przygotowaną na potrzeby publikacji rozszerzoną i uaktualnioną wersją referatu wygłoszonego na Konferencji „Konstytucja RP z 1997 r. - założenia teoretyczne a praktyka”, UAM, Poznań, 11 października 2017 r.

${ }^{1} \mathrm{Na}$ temat powstawania Konstytucji RP por. R. Chruściak, W. Osiatyński, Tworzenie Konstytucji w Polsce w latach 1989-1997, Warszawa 2001.
} 
i w tych, które, nie tylko w Europie Środkowej i Wschodniej, ale także w innych regionach świata ${ }^{2}$, uczyniły z ustaw zasadniczych jedno z głównych narzędzi demokratycznej transformacji, potwierdzają tę ocenę. Podobnie jak czynią to ustrojowe traktaty Unii Europejskiej przyjęte w ramach reformy lizbońskiej.

Nie wydaje się też, że Konstytucja z 1997 r. przestała odpowiadać potrzebom społeczeństwa, którego ambicją jest budowanie sprawnego państwa chroniącego wolność jednostki, przyjaznego ludziom, zapewniającego ochronę przed dyskryminacja wszelkiego rodzaju, w tym przed wykluczeniem społecznym, oraz cenionego jako wiarygodny i kooperatywny partner we wspólnocie narodów. Jest to akt nowoczesny, stwarzający funkcjonalne ramy działania państwa i społeczeństwa obywatelskiego. Stwarza warunki do realizacji koncepcji dobrego rządzenia, tak jak jest ona rozumiana w doktrynie międzynarodowej ${ }^{3}$.

Konstytucja ta ma oczywiście jedną słabość, która jest jednak immanentna dla aktów tego typu w państwach demokratycznych. Wynika ona jednak z ich cnoty i to zapewne wystarcza za jej usprawiedliwienie. Ta słabością i cnota zarazem jest to, że zakłada działanie w dobrej wierze tych, którzy sa powołani do wykonywania postanowień ustawy zasadniczej. W tym sensie można do Konstytucji z 1997 r. zastosować komentarz, jaki pod adresem amerykańskiej konstytucji sformułował u początków jej trwajacej dwa i pół wieku historii John Adams, drugi prezydent USA, piszacc, że została ona ustanowiona dla społeczeństwa moralnego, a jest nieadekwatna do rządów działajaccych w innych warunkach ${ }^{4}$.

Konstytucja RP ustanawia wprawdzie mechanizmy korekcyjne wobec działań ją naruszających, ale podobnie jak inne ustawy zasadnicze państw demokratycznych, może być bezsilna wobec bezpośrednich na nią zamachów. Oparta jest bowiem na założeniu, że procedury demokratyczne i sądowa kontrola konstytucyjności prawa co do zasady powinny wystarczyć do obrony demokracji i państwa prawnego ${ }^{5}$.

Konstytucja RP nie formułuje prawa do oporu (ius resistendi) ani prawa do nieposłuszeństwa obywatelskiego (civil disobedience) na wypadek, kiedy to oczekiwanie miałoby pozostać płonne. Postanowienia tego typu zawieraja niektóre inne ustawy zasadnicze, w tym np. Konstytucja Słowacji w art. 32: „Obywatele maja prawo stawiać opór wobec każdego, kto by odrzucał demokratyczny porządek podstawowych praw i wolności człowieka wynikający z niniejszej Konstytucji, jeżeli działalność organów konstytucyjnych i skuteczne zastosowanie środków ustawowych staną się niemożliwe”. Dość powszechny

\footnotetext{
${ }^{2}$ Por. spośród wielu np. konstytucje Republiki Południowej Afryki, Timoru Leste lub Nepalu.

${ }^{3} \mathrm{Na}$ temat tej koncepcji por. np. S. Agere, Promoting Good Governance: Principles, Practices and Perspectives, Commonwealth Secretariat, London 2000, zwłaszcza s. 2-10, a także J.F. Helliwell, H. Huang, S. Grover, S. Wang, Good Governance and National Well-being. What Are the Linkages?, OECD Working Papers on Public Governance, 2014, <http://www.oecd-ilibrary. org/governance/good-governance-and-national-well-being_5jxv9f651hvj-en>.

${ }^{4}$ From John Adams to Massachusetts Militia, 11 October 1798, National Archives and Records Administration, Founders Online, <https://founders.archives.gov/documents/Adams/ 99-02-02-3102>.

${ }^{5}$ Por. rozwiniętą przez doktrynę niemiecką koncepcję demokracji zdolnej do obrony (wehrhafte lub streitbare Demokratie).

${ }^{6}$ Por. też np. § 54 Konstytucji Estonii lub art. 20 § Ustawy zasadniczej Niemiec: „Wobec każdego, kto usiłuje obalić ten porządek [konstytucyjny - ZK], wszystkim Niemcom przysługuje prawo
} 
jest jednak pogląd, że niezależnie od ewentualnego milczenia konstytucji w tej materii, prawo do nieposłuszeństwa obywatelskiego należy odczytać z przepisów o prawach jednostki

Jak wiadomo jednak, nie tylko polityczne uwarunkowania determinuja wpływ konstytucji na kształt instytucji publicznych, procesy rządzenia i sytuację jednostki. Jest on też $\mathrm{w}$ poważnym stopniu wypadkową naturalnego napięcia, które cechuje relację pomiędzy tekstem ustawy zasadniczej a ewoluującym otoczeniem społecznym, politycznym i gospodarczym. Przymiotem bowiem konstytucji jako kotwicy porządku prawnego jest jej stabilność, chroniąca państwo i społeczeństwo przed dryfowaniem ustroju i porządku prawnego. Dynamika zmian społeczno-politycznych jest natomiast zjawiskiem obiektywnym, stymulowanym nie tylko planowanymi i w swym zamierzeniu racjonalnymi działaniami, lecz także wydarzeniami niezależnymi od tych, którzy z tytułu zajmowanej pozycji mogą wpływać na życie społeczeństwa, a mającymi charakter zarówno wewnętrzny, jak i zewnętrzny. Niemałą rolę odgrywaja przy tym emocje społeczne, których natura, kierunek i energia nie dają się $\mathrm{w}$ pełni przewidzieć. Ta dynamika zmian społeczno-politycznych stanowi stałe wyzwanie wobec tekstu ustawy zasadniczej, słusznie chronionego utrudnioną w porównaniu z ustawami zwykłymi procedura jego zmiany. Konstytucjonalizm wypracował metody radzenia sobie z tym problemem, które w doktrynie niemieckiej opisane są za pomocą rozróżnienia pomiędzy rozwojem w sensie adaptacyjnym (Verfassungswandel) a zmianami konstytucji (Verfassungsänderung) ${ }^{8}$.

Rozwój konstytucji następuje przez jej wykładnię, bez zmian tekstu. Zmiany polegaja natomiast na rewizji samych jej postanowień. Wnioski wynikające nie tylko z hierarchii źródeł prawa, lecz także z praktyki konstytucyjnej państw demokratycznych przemawiają za tym, aby dopóty, dopóki jest to możliwe, podążać torem rozwoju konstytucji, a dopiero wtedy, kiedy napięcia między tekstem ustawy zasadniczej a jej otoczeniem nie da się rozwiąać na tej drodze, sięgać do zmian w konstytucji. Oznacza to, że jeśli ewolucja otoczenia pozostaje w ramach ustrojowych ustalonych przez konstytucję, to z reguły wystarcza pierwsza z metod, chyba że potrzebne jest wprowadzenie zupełnie nowych rozwiązań, np. instytucjonalnych lub proceduralnych, lub też usunięcie ewidentnych braków lub pomyłek, które ujawniły się w procesie stosowania ustawy zasadniczej. Dla takiego podejścia konieczne jest jednak zachowanie niezależnej od polityki, a tym samym od parlamentu i rządu, sądowej kon-

do oporu, jeżeli inny sposób przeciwdziałania nie jest możliwy”. Warto przypomnieć, że już art. II francuskiej Deklaracji praw człowieka i obywatela z 1789 r. zaliczał prawo oporu wobec opresji do przyrodzonych i niezbywalnych praw człowieka, obok wolności, własności i bezpieczeństwa.

${ }^{7}$ Por. M.J. Falcón y Tella, Civil Disobedience, The Eric Castrén Institute of International Law and Human Rights, Martinus Nijhoff Publishers, Leiden-Boston 2004, s. 86. Dla J. Rawlsa „Problem prawa do obywatelskiego nieposłuszeństwa jest kluczowym testem dla wszelkich teorii moralnych podstaw demokracji” - idem, A Theory of Justice, rev. edn., Cambridge, Massachusetts, 1999, s. 319. Por. też K. Brownlee, Civil Disobedience, w: The Stanford Encyclopedia of Philosophy (Fall 2017 Edition), E.N. Zalta (ed.), <https://plato.stanford.edu/archives/fall2017/entries/ civil-disobedience/>.

${ }^{8}$ Por. B.-O. Bryde, Verfassungsentwicklung. Stabilität und Dynamik im Verfassungsrecht der Bundesrepublik Deutschland, Baden-Baden, 1982, s. 17 i n., zwł. s. 21. 
troli konstytucyjności prawa ${ }^{9}$, co w polskim przypadku oznacza pełną niezależność Trybunału Konstytucyjnego (TK) i niezawisłość jego sędziów. W innym wypadku może, jak wiadomo, zabraknąć hamulców przeciwdziałających rozwojowi konstytucji i praktyki konstytucyjnej contra legem fundamentalem. Dlatego też działania podważające niezależność sądownictwa konstytucyjnego i niezawisłość jego sędziów nie tylko naruszaja konstytucję, lecz - co więcej faktycznie uniemożliwiają zgodny z wolą suwerena rozwój państwa opartego na prawie tak, jak je rozumieją nowoczesne wolne społeczeństwa i jak je rozumiał suweren w $1997 \mathrm{r}$.

Inaczej sprawy się maja, jeśli chodzi o przyjęcie nowej konstytucji lub przeprowadzenie zasadniczej rewizji dotychczasowej, kiedy fundamentalne rozwiązania ustrojowe, lub istotna ich część, dobiegły kresu swych możliwości, co odpowiada w języku Johna G.A. Pococka „momentowi Machiavellego”10. Jeszcze raz odwołując się do natury konstytucji, do wymogu jej stabilności, wydaje się, że zainicjowanie dyskusji na ten temat powinno opierać się na wykazanej na podstawie wszechstronnej analizy niemożności prawidłowego funkcjonowania i rozwoju państwa bez takiego kroku. Powinna to być ocena obiektywna i wyważona, a nie wynikająca jedynie z chęci politycznego odcięcia się od aktualnej ustawy zasadniczej przez pewną część klasy politycznej lub oparta na chęci upamiętnienia okragłej rocznicy, nawet gdy ta ma niezaprzeczalne miejsce w historii narodu. Trzeba natomiast pamiętać o słowach znanego konstytucjonalisty Bruce'a Ackermana, odnoszacych się wprawdzie bezpośrednio do amerykańskiego konstytucjonalizmu, ale mających zapewne szersze zastosowanie. Pisze on: „Nie możemy budować lepszej przyszłości przez odcinanie się od przeszłości. [...] Moim celem tutaj jest przekonać was, że wzorce naszej obecnej konstytucyjnej dyskusji i praktyki sięgają głębszego porządku, niż ktoś mógłby zakładać, porządku, który najlepiej można rozpoznać poprzez refleksję nad przebiegiem historycznego rozwoju [...]"11.

Innymi słowy, należy gruntownie ocenić, czy potencjał dostosowywania konstytucji drogą jej interpretacji opartej na wiedzy i doświadczeniu został już wyczerpany i czy pojawiły się obiektywnie wystarczająco silne przesłanki, które przemawiaja za fundamentalną reformą konstytucyjną. Nawet jednak udzielenie odpowiedzi pozytywnej na te pytania nie jest warunkiem wystarczającym. Centralne znaczenie ma także silne i świadome zaangażowanie społeczne na rzecz zmian, wywodzące się ze wspólnego doświadczenia politycznego i świadomości długotrwałych skutków zamierzonych kroków. Innymi słowy, powinien wystapić, jak to ujmuje B. Ackerman, „moment konstytucyjny" (constitutional moment). Moment ten jest mierzony przez zdecydowane poparcie w społeczeństwie dla idei reformy konstytucji w trzech wymiarach: głębokości (jakość społecznego zaangażowania), zasięgu poparcia i determinacji zwolenników, aby zaangażować się na rzecz reformy ${ }^{12}$. Znaczenie tego

${ }^{9}$ Por. B. Ackerman, We the People. Foundations, t. 1, Cambridge, Massachusetts, 1991, s. 10.

10 J.G.A. Pocock, The Machiavellian Moment: Florentine Political Thought and the Atlantic Republican Tradition, PUP, Princeton 1975, s. VIII.

11 B. Ackerman, op. cit., s. 5.

12 Ibidem, s. 272 i n.; por. też Wywiad z prof. M. Matczakiem Nie odwiqzujcie Odyseusza, „Tygodnik Powszechny” z 11 marca 2016, <https://www.tygodnikpowszechny.pl/nie-odwiazujcie-odyseusza-32718>. 
momentu dobitnie wyjaśnia András Sajó, nawiązując do propozycji Bruce'a Ackermana: „Koncepcję "konstytucyjnego momentu“ charakteryzuja trwałe konstytucyjne rozwiązania, które wynikają ze specyficznych, emocjonalnie podzielanych odpowiedzi na wspólne podstawowe polityczne doświadczenia"13.

Anna Młynarska-Sobaczewska, powołując się na koncepcję Bruce’a Ackermana, pyta w odniesieniu do Polski: „Czy to już moment konstytucyjny?”14. To jest niewątpliwie ważkie pytanie i zostało sformułowane w ważnej publikacji, która ukazała się we współpracy z Kancelarią Prezydenta. Autorka skłonna jest, jak się wydaje, zjawisko kryzysu konstytucyjnego uznać za źródło momentu konstytucyjnego i zastanawia się, czy mamy w Polsce do czynienia z takim kryzysem. Według niej: „Nie jest nawet objawem kryzysu konstytucyjnego, że podmiot władzy nadużywa jej albo zachowuje się sprzecznie z regułami - dopóki konflikt da się przezwyciężyć normalnymi metodami i za pomoca przewidzianych w Konstytucji instrumentów". Rozumiem, że autorce chodzi o to, że trudno mówić o kryzysie konstytucyjnym, kiedy dochodzi do takich nadużyć, ale np. niezależny sąd konstytucyjny złożony z niezawisłych sędziów, którego wyroki zgodnie z ustawą zasadniczą są należycie ogłaszane i wchodzą w życie, jest w stanie przywrócić poszanowanie konstytucji; kiedy tryb procedury pociagania do odpowiedzialności tych, którzy dopuszczają się takich nadużyć, jest funkcjonalny i można skutecznie użyć takiej procedury (patrz impeachment w USA), w każdym razie na etapie formułowania zarzutów, co wymaga niezależności kompetentnych organów od tych, którzy o te nadużycia sa podejrzewani. Rozumiem też, że zdaniem autorki nie jest „normalna metodą przezwyciężenia konfliktu konstytucyjnego" trwanie przez podmiot dopuszczajacy się nadużycia władzy lub innych zachowań sprzecznych z regułami porządku konstytucyjnego przy swoim stanowisku i odrzucanie postulatów naprawy tej sytuacji zgodnie z powszechnie przyjętymi zasadami konstytucjonalizmu. Ani nie jest taką metodą próba zmiany porządku konstytucyjnego przez tego, kto tych kroków się dopuszcza, a w zmianie poszukuje usprawiedliwienia własnych działań. I wreszcie, że nie jest taką „normalna metodą" manipulowanie składem sądu konstytucyjnego, aby zapewnić sobie orzecznictwo potwierdzające legalność naruszeń konstytucji. Z takim rozumowaniem wypadałoby się zapewne zgodzić.

Dalej autorka pisze, że kryzys konstytucyjny polega na zakwestionowaniu konstytucyjnych reguł działania, czyli zapisanego w konstytucji systemu operacyjnego państwa; tkwi w braku zgody na konstytucyjne regulacje; obnaża deficyty i mankamenty samego konstytucyjnego zaprojektowania. Nie wiadomo, czy te objawy muszą wystapić łącznie, czy też jeden z nich wystarcza, aby mówić o kryzysie. Mają one wszak bardzo różną naturę. Co więcej, brakuje wyjaśnienia, przez kogo i w jakiej formie może dojść do owego zakwestionowania, aby uznać je za legitymizowane i za posiadające znamiona „momentu Machiavellego”. Czy wystarczać ma tutaj np. stanowisko niektórych sił politycznych lub też rozproszone wypowiedzi w mediach, czy też pojedyncze diagnozy naukowe?

13 A. Sajó, Constitution without the constitutional moment: a view from the new member states, „International Journal of Constitutional Law” 3(2-3), 2005, s. 243.

${ }_{14}$ Opinia opublikowana w: „Dziennik Gazeta Prawna” z 21 grudnia 2017, nr 247, Dodatek Informacyjno-Promocyjny, opublikowany w partnerstwie z Kancelarią Prezydenta „Wspólnie o Konstytucji”. 
Jeśli w społeczeństwie dominuje zgoda co do utraty przez konstytucję zdolności regulowania procesów rządzenia lub pozycji jednostki, zapewne można mówić o kryzysie konstytucyjnym. Ale gdyby przyjać, że tego typu ocena ma charakter odosobniony, trudno byłoby uznać ją za jego przejaw. Natomiast kompetentne organy państwa winny w takiej sytuacji stosować i egzekwować postanowienia ustawy zasadniczej. Nawet taka odosobniona ocena może jednak znamionować kryzys konstytucyjny, jeśli kieruje ona działaniami władz publicznych i prowadzi do naruszania ustawy zasadniczej. Taka sytuacja nie uzasadnia jednak zmiany konstytucji, a przemawia za przywróceniem porządku konstytucyjnego.

Później A. Młynarska-Sobaczewska pisze o przykładach „zagadnień, które wskazują na nieprecyzyjną lub niepełną regulację konstytucyjną, które, jak rozumiem, mają ilustrować występowanie kryzysu konstytucyjnego. Nie miejsce tu na dyskusję nad podanymi przez autorkę przykładami, ponieważ wymagałoby to osobnego opracowania, ale nie ulega wątpliwości, że tak jak zapewne każdej konstytucji, także ustawie zasadniczej z $1997 \mathrm{r}$. takie regulacje nie są obce ze zrozumiałych dla każdego konstytucjonalisty względów, a zwłaszcza z uwagi na konieczność unikania kazuistyki w redakcji ustawy zasadniczej. Trzeba natomiast $\mathrm{z}$ całą mocą podkreślić, że jeśli incydentalnie nieprecyzyjna lub niepełna konstytucyjna regulacja miałaby zostać uznana za przejaw kryzysu konstytucyjnego, to należałoby dojść do wniosku, że wszystkie kraje demokratyczne znajdują się w nieustajacym kryzysie tego rodzaju. Oczywiście taki wniosek byłby bezzasadny, jako że w tych krajach sądowa wykładnia ustawy zasadniczej, której celem jest wyjaśnienie jej postanowień wówczas, kiedy zachodzi taka potrzeba, jest traktowana jako część samej konstytucji, w każdym razie w sensie materialnym.

Byłoby dobrze, gdyby w naszych dyskusjach wziąć pod uwagę rozważania B. Ackermana, który troskliwie wyodrębnia cztery etapy tzw. wyższego ustawodawstwa, dotyczącego węzłowych zagadnień ustrojowych, w odróżnieniu od rozwoju (ew. zmian) konstytucji, mieszczących się w ramach tzw. zwykłej polityki. Etapy te obejmują: sygnalizację potrzeb w zakresie zmian konstytucji, opracowanie propozycji, mobilizację dyskusji publicznej i - jeśli poprowadzi to do szerokiego i świadomego poparcia społecznego dla zmian - kroki prawodawcze ${ }^{15}$.

Konkludując ten wątek - nie ulega wątpliwości, że w procesie optymalizacji naszej Konstytucji zawarte w niej rozwiązania moga zostać uzupełnione czy doprecyzowane. Co więcej, zawsze otwarte pozostają pytania dotyczace sposobu ujęcia rozmaitych wersji demokratycznych instytucji ustrojowych (np. system parlamentarno-gabinetowy a prezydencki, dwu- lub jednoizbowy parlament itd.). A. Młynarska-Sobaczewska wskazuje w tym kontekście na brak określenia statusu prokuratury w Konstytucji $\mathrm{RP}^{16}$. Zgłaszane propozycje po-

15 B. Ackerman, op. cit., s. 266 i 267.

${ }_{16}$ Przypomnijmy, że trudno było uzgodnić wybór pomiędzy modelem niezależnej od władz politycznych prokuratury a powierzeniem odpowiedzialności za sprawowanie funkcji prokuratora generalnego organowi na wskroś politycznemu, jakim jest minister sprawiedliwości. W konsekwencji w okresie ostatnich 20 lat, po początkowym powierzeniu funkcji prokuratora generalnego ministrowi sprawiedliwości, już dwukrotnie doszło do zmiany modelu. I nie wydaje się, że obecny stan rzeczy ma charakter ostateczny, chociażby w średnim terminie. 
winny jednak pozostawać w ramach wyznaczonych dorobkiem współczesnego konstytucjonalizmu. A wyznaczają je m.in. zasada demokratycznego państwa prawnego, zasada poszanowania godności człowieka oraz jego wolności i praw, oparcie rozwiązań ustrojowych na podziale władz i zagwarantowaniu niezależności sądownictwa od władzy ustawodawczej i wykonawczej, a także zasady pluralizmu politycznego, swobodnego funkcjonowania społeczeństwa obywatelskiego oraz na wolności mediów zarówno tradycyjnych, jak i posługujących się Internetem. Wszelkie niejasności lub niedopowiedzenia w tym zakresie na etapie inicjowania zmian grożą dysfunkcją aktualnego systemu konstytucyjnego, a w skrajnym przypadku zniweczeniem, a nie umocnieniem demokratycznego ustroju. Takie skutki mogą także przynieść wypowiedzi wysokich funkcjonariuszy państwa mające na celu dezawuowanie obowiąującej ustawy zasadniczej ze względu na jej rzekomo „wątpliwe pochodzenie”, co ma uzasadnić propozycje jej zastapienia.

Należy założyć, że im głębsza ma być interwencja w tekst konstytucji, tym bardziej zasadne staje się pytanie, czy występuje ów Ackermanowski moment konstytucyjny. Warto pamiętać, że - jak to podkreśla A. Sajó - wadą konstytucji, które rodzą się bez błogosławieństwa tego momentu, jest to, że „nie przyczyniają się one do sensu wspólnoty, lub kształtowania wspólnej tożsamości, pośród członków społeczeństwa [...]"17. Czy przy obecnych głębokich podziałach w społeczeństwie istnieją warunki do szerokiego i w pełni świadomego konsensusu wokół propozycji konstytucyjnych? A. Młynarska-Sobaczewska pisze barwnie, acz nie bez racji, o naszej polskiej plemiennej wojnie ${ }^{18}$. Czy jednak owa „plemienna wojna”, wynika z utrwalonych w konstytucji zasad demokratycznego i wolnościowego ustroju? Czy też bierze się ona raczej z ich podważania? A jeśli w tej sytuacji receptą na owa „wojnę” ma być nowa konstytucja, czy jej przyjęcie ma prowadzić do odrzucenia tych zasad? Zapewne nie służy generowaniu momentu konstytucyjnego argumentacja, że obecna konstytucja „jest konstytucja elit”, a jej obrońcy są motywowani chęcią obrony własnego status quo.

Zachowując wszelkie proporcje, należy pamiętać, a zwłaszcza powinni to czynić sternicy nawy państwowej, o słowach Jana Jakuba Rousseau adresowanych do Polaków dwa i pół wieku temu, który nawiązując do swojej Umowy społecznej, pisał, że podczas ustanawiania czy reformowania konstytucji z uwagi na towarzyszace temu spory powstaje poważne ryzyko osłabienia państwa i anarchii. Przestrzegał, że w takiej chwili „najmniejsze wstrzaśńnienie może wywrócić wszystko. Waszą [narodu] jest więc rzeczą zapewnić sobie za wszelką cenę okres spokoju, podczas którego można by bez ryzyka pracować nad sobą i odmłodzić swą konstytucję"19.

Wydaje się, że punktem wyjścia integrującej, zasypującej podziały tam, gdzie to jest możliwe, budującej wspólną tożsamość obywatelską dyskusji nad reformami konstytucyjnymi powinna być odbudowa wzajemnego szacunku i zaufania, bezpieczeństwa prawnego, wiary w dobro wspólne, rzetelne respektowanie zasad partycypacji politycznej. To powinien być etap poprzedzajacy

\footnotetext{
17 A. Sajó, op. cit., s. 243.

18 Por. Opinia, op. cit.

19 J.J. Rousseau, Uwagi nad rzqdem Polski, Kraków 1924, s. 99.
} 
samo wypracowywanie konkretnych propozycji zmian konstytucyjnych. Warunkiem tego procesu jest bezwzględne poszanowanie zasad demokratycznego ustroju zakotwiczonych w obowiązującej Konstytucji. Tylko tą drogą możliwe jest dotarcie do tego, co wcześniej zostało określone jako „moment konstytucyjny”. Ten bowiem nie może powstać wskutek arbitralnego odrzucenia przez część klasy politycznej istniejącej ustawy zasadniczej.

III. W kontekście tych uwag należy powrócić do pytania, czy karta praw zawarta w polskiej Konstytucji wymaga zasadniczej rewizji lub zastapienia przez nową regulację ze względu na utratę przez jej aksjologiczną osnowę waloru adekwatności lub z uwagi na jej niedoskonałości, w tym redakcyjne.

Niewątpliwie wyżej przytoczone oceny naszej ustawy zasadniczej dotyczace jej osadzenia w nowoczesnym konstytucjonalizmie odnoszą się również do zawartej w niej karty praw. Warto zwrócić uwagę, że w swych istotnych punktach karta ta jest bardzo podobna do regulacji zawartych w nowszych konstytucjach uchwalonych nie tylko w zachodniej hemisferze, w tym w Europie Środkowej i Wschodniej, lecz także w innych regionach świata, a zwłaszcza w krajach, które odrzuciły obca dominację lub przeszły demokratyczną transformację. Wynika to zapewne z upowszechniania idei praw człowieka poprzez prawo międzynarodowe i związane z nim orzecznictwo sądów i organów o zbliżonym charakterze $\mathrm{z}$ jednej strony, a $\mathrm{z}$ drugiej - $\mathrm{z}$ uniwersalnych wpływów nowoczesnego konstytucjonalizmu.

Poszukując jednak dokładniejszej odpowiedzi na postawione pytanie, chciałbym skoncentrować się na następujących dwóch punktach:

- po pierwsze: jaka jest kondycja naszej konstytucyjnej karty praw w świetle kryteriów, które przyświecały jej konstruowaniu?

- po drugie: jakie kwestie wymagałyby rozważenia w ramach dyskusji nad ewentualnymi zmianami konstytucji?

\section{Kryteria konstruowania konstytucyjnej karty praw}

Podczas dyskusji nad nową konstytucją u początków naszej transformacji ustrojowej uznano, że karta praw powinna spełniać m.in. następujące główne kryteria:

1) adekwatności do dominujących $w$ społeczeństwie ocen relacji między jednostką a wspólnota,

2) zgodności z międzynarodowymi standardami praw człowieka,

3) uniwersalności treści,

4) jurydyczności ${ }^{20}$.

${ }^{20}$ Por. Z. Kędzia, Kryteria kształtowania konstytucyjnego katalogu praw, wolności, obowiazków człowieka i obywatela; zamieszczone w opracowaniu stanowiącym syntezę ogólnopolskiego programu badawczego: Poznańskie Centrum Praw Człowieka Instytut Nauk Prawnych PAN: Prawa, wolności i obowiazki człowieka $i$ obywatela $w$ nowej polskiej konstytucji, red. naukowy Z. Kędzia, Poznań 1990, s. 36 i n. 
Lektura współczesnych konstytucji przekonuje, że te kryteria mają w zasadzie powszechne zastosowanie, aczkolwiek ich zharmonizowanie jest niekiedy wyzwaniem samym w sobie.

\subsection{Kryterium adekwatności do dominujących w społeczeństwie ocen relacji między jednostką a wspólnotą}

Zastosowanie tego kryterium jest szczególnie trudne. Przede wszystkim dynamika ocen dotyczących pożądanej treści relacji między jednostką a wspólnota, a także poziom percepcji odnoszacych się do tej relacji problemów, powoduja, że ustalenia w tej mierze są zabiegiem nader skomplikowanym. W dyskusjach prowadzonych w początkach transformacji istotne wydawały się w tym zakresie takie czynniki, jak doniosłość materii oraz zasięg poparcia dla zgłaszanych propozycji lub ich odrzucenia w wypowiedziach publicznych. Nawet zdając sobie sprawę z ułomności takiego podejścia, trudno było pod presją czasu przyjąć inne rozwiązanie. Było ono też o tyle usprawiedliwione, że stosunkowo duży entuzjazm wokół głównych celów transformacyjnych (niepodległość, demokracja, wolność, skok gospodarczy) w tym okresie pozwalał na wychwycenie tego, co wydawało się przeważajace w opinii publicznej. Ów entuzjazm sprzyjał także otwartości na kompromis, która z kolei ułatwiała odcyfrowanie wektorów debaty publicznej.

Czas romantyzmu transformacyjnego mija jednak zwykle dość szybko, jak podpowiada doświadczenie wielu krajów. Po nim następuje z reguły okres sporów, często o rewindykacyjnym lub populistycznym charakterze. Podobnie było w Polsce. Początkowo personalizm ${ }^{21}$ w tłumaczeniu na takie wartości, jak godność człowieka, wolność, tolerancja i szacunek dla innych, przyzwoitość, równość i zakaz dyskryminacji, inkluzywność, zdawał się dostarczać wystarczającej podstawy do rysowania konstytucyjnej pozycji jednostki we wspólnocie. Czy dzisiaj te odniesienia wywołuja to samo echo w społeczeństwie? Odpowiedź nie jest łatwa. Może zresztą to pytanie należy postawić inaczej: czy odwołanie się do tych, zdawałoby się, wspólnych i niepodważalnych wartości przeważa wobec demagogii i taniej propagandy, czy wartości te mają taka siłę motywacyjna, że pozwolą na skuteczny opór wobec zarządzania poprzez populistyczne emocje?

Jeszcze niedawno wydawać się mogło, że poglądy, które zostały intelektualnie w zasadzie porzucone i przetrwały jedynie na marginesach debaty, nie będą więcej traktowane jako odkrywcze i ważne. To oczekiwanie było jednak, jak się okazuje, w dużym stopniu przedwczesne. Na przykład niedawno został opublikowany artykuł na jednej z nobliwych stron internetowych, w którym można przeczytać, że według „intelektualistów” i „liberałów” wolność ma polegać „na robieniu tego, co ktoś chce, byle tylko nie naruszać wolności drugiego człowieka”. To z kolei oznacza dla autora, że: „Po pierwsze, liberalna definicja wolności pozwala na wyrządzanie krzywdy drugiemu człowiekowi. Dla przykładu, gdy ktoś podpala komuś dom czy go oczernia, to przecież nie narusza

${ }^{21}$ Chodzi tu o ogólny nurt personalizmu, który umiejscawia autonomiczną osobę ludzką w centrum dyskursu społecznego i czyni z niej punkt odniesienia porządku wspólnoty ludzkiej, a nie o jego szczególny kierunek. 
jego wolności, a jedynie jego majątek lub dobre imię. Wolność rozumiana na sposób liberałów pozwala zatem wyrządzać drugiemu człowiekowi dowolna krzywdę, byle tylko nie naruszać czyjejś wolności” ${ }^{22}$. Niestety tego rodzaju argumenty znajduja posłuch i w ten sposób wyznaczaja jeden z biegunów dyskursu wokół podstaw aksjologicznych konstytucyjnej karty praw. Dlatego też nie można pozostawić ich bez komentarza.

Należy zatem przypomnieć, że przedstawiciele doktryny liberalnej od jej zarania podkreślali, że wolność nie może oznaczać braku jakichkolwiek więzów krępujących jednostkę. Nie oznacza samowoli i braku odpowiedzialności, nieuchronnie prowadzacych do anarchii. Wypowiedź Johna Locke'a jest jednoznaczna: „Wolność nie jest zatem [...] wolnością każdego do tego, co mu się podoba, do życia, jakie mu się podoba i nieskrępowania żadnymi prawami” ${ }^{23}$. Jan Jakub Rousseau, który bardziej był demokratą niż liberałem, a to rozróżnienie w jego czasach miało znaczenie, podkreślał: „Na próżno chciano utożsamiać niezależność i wolność. Są to dwie rzeczy tak różne, że się wzajemnie wykluczają. Gdyby każdy czynił, co mu się podoba, popełniałby często to, co innym się nie podoba i wówczas nie mielibyśmy państwa wolnego. Wolność mniej polega na przejawianiu swojej woli, jak na tym, aby nie podlegać woli cudzej”"24. Karol Monteskiusz, rozważając potrzebę ustalenia granic swobody jednostki, stwierdził, że „istnieją przypadki, w których trzeba na chwilę narzucić wolności zasłonę, jak się przesłania posagi bogów"25.

Czy jednak kontrowersje wokół elementów aksjologii konstytucji nie sugeruja, że nadszedł czas, aby traktować katalog praw jednostki jako zestaw „uzgodnień praktycznych”, który nie potrzebuje fundamentu wspólnych podstawowych wartości? Jacques Maritain, wybitny personalista, kiedy mówił o Powszechnej deklaracji praw człowieka z 1948 r., użył właśnie tego określenia, kwestionując możliwość zgody co do filozoficznych podstaw praw człowieka w silnie zróźnicowanym świecie ${ }^{26}$. Chociaż, z drugiej strony, pamiętać należy, że to właśnie Maritain zgodnie z doktryną personalizmu zaproponował oparcie Deklaracji na uniwersalnej wartości, jaka jest godność człowieka.

Wracając do naszego społeczeństwa - czy jego zróżnicowanie poszło już tak daleko, że powinniśmy za Maritainem mówić o uzgodnieniu praktycznym w przypadku naszej konstytucyjnej karty praw i zrezygnować z odwołań do jej podstawy aksjologicznej? Czy trafna jest obserwacja A. Sajó, według którego: „Ludzie będą musieli nauczyć się żyć w świecie, w którym tradycyjne formy tożsamości konstytucyjnej i tradycyjne konstytucyjne gwarancje wolności mają być zastapione nowymi, pragmatycznymi formami ochrony interesów”27.

${ }^{22}$ M. Dziewiecki, Wolna „wolność” czy wolny człowiek?, <http://www.opoka.org.pl/biblioteka/F/ FE/wolnosc_czl.html>.

${ }^{23}$ J. Locke, Drugi traktat o rzqdzie, w: idem, Dwa traktaty o rzqdzie, Warszawa 1992, s. 369.

${ }^{24}$ J.-J. Rousseau, Lettres écrites de la montagne, w: Collection complète des oeuvres, vol. 6 , Genève 1780-1789, in-4 $4^{\circ}$, édition en ligne: <www.rousseauonline.ch>, version du 7 octobre 2012, tłum. fragmentu za: A. Peretiatkowicz, Jan Jakub Rousseau. Filozof demokracji społecznej, Poznań 1949 , s. 142 .

${ }^{25}$ Montesquieu, O duchu praw, Warszawa 1957, ks. XII, rozdz. 19.

${ }^{26}$ J. Maritain, Man and the State, Catholic University of America Press, Washington 1998 (oryg. University of Chicago Press 1951), s. 76-77.

${ }^{27}$ A. Sajó, op. cit., s. 244. 
A zatem, czy należy dojść do wniosku, że brakuje normatywnej legitymizacji konstytucyjnej karty praw, a ma ona jedynie legitimizację legalna, będąc formą zapisania w ustawie zasadniczej owych uzgodnień praktycznych i ochrony interesów? A w konsekwencji: czy prawa człowieka i obywatela maja być w pełni zakładnikiem woli parlamentarnej większości, nawet gdyby chodziło o większość potrzebną do zmiany konstytucji?

Nie wydaje się, abyśmy byli w tym punkcie ani w Polsce, ani w innych państwach, które wybrały opcję demokratyczną. Należy przyjąć, że argumentacja personalistyczna sytuująca wolna, a zarazem odpowiedzialną jednostkę i ochronę jej godności w centrum dyskursu nadal oferuje podstawowe uzasadnienie karty praw. Natomiast w dobie postprawdy i postargumentów konieczne jest zdwojenie wysiłków na rzecz upowszechnienia w społeczeństwie wiedzy o prawach człowieka i pożądanych postaw w tej mierze, na rzecz nauczania o podstawowych wartościach demokratycznych i humanistycznych adresowanego do wszystkich segmentów i grup społecznych. Niestety zawiodła dość powszechna nadzieja (i chyba musiała zawieść), że raz przeprowadzone reformy w duchu demokracji, państwa prawa i praw człowieka doprowadza niejako automatycznie do ostatecznego zinternalizowania tych idei w skali społecznej. Okazuje się, że wymagają one „odnawialnej energii”.

O tym, że nie można traktować demokratycznego przełomu politycznego jako jednorazowego aktu, którego osiagnięcia będą trwale bezpieczne, przenikliwie przekonywał m.in. inny wybitny personalista, jakim był Karol Wojtyła. Już od pierwszej swojej encykliki papieskiej Redemptor hominis ${ }^{28}$ podkreślał fundamentalne znaczenie praw człowieka dla jednostki i wspólnoty politycznej. Ale nie traktował ich jako dobra danego raz na zawsze. W orędziu na XXXII Światowy Dzień Pokoju w 1999 r., wieńczącym 50 rocznicę uchwalenia Powszechnej deklaracji praw człowieka, pisał: „Tylko wówczas, gdy kultura praw człowieka, respektująca różne tradycje, stanie się integralną częścią moralnego dziedzictwa ludzkości, będzie można spokojnie i z ufnością patrzeć w przyszłość" formacji ustrojowej w Europie Środkowej i Wschodniej, dotyczącą m.in. kwestii ustrojowych o zasadniczym znaczeniu dla praw jednostki, należy bardziej odczytywać jako przestrogę, aby nie zbaczać z drogi, niż samo wytyczenie tej ostatniej. Nawiązując do myśli Leona XIII, pisał bowiem, że „organizacja społeczeństwa oparta na trzech władzach - prawodawczej, wykonawczej i sądowniczej odzwierciedla realistyczną wizję społecznej natury człowieka, która wymaga odpowiedniego prawodawstwa dla ochrony wolności wszystkich. Dlatego jest wskazane, by każda władza była równoważona przez inne władze i inne zakresy kompetencji, które by ją utrzymywały we właściwych granicach. Na tym właśnie polega zasada "państwa praworządnego«, w którym najwyższa władzę ma prawo, a nie samowola ludzi”. I dalej z całą wnikliwością podkreślał: „Historia uczy, że demokracja bez wartości łatwo się przemienia w jawny lub zakamuflowany totalitaryzm”.

${ }^{28}$ Jan Paweł II, encyklika Redemptor hominis z 4 marca 1979 r., par. 17, <https://opoka.org. pl/biblioteka/W/WP/jan_pawel_ii/encykliki/r_hominis.html>.

${ }^{29}$ Orędzie na XXXII Światowy Dzień Pokoju 1999, <https://www.deon.pl/religia/serwis-papieski/jan-pawel-ii/oredzia/art,32,oredzie-na-xxxii-swiatowy-dzien-pokoju-1999.html>. 
Wydaje się, że poglądy Jana Pawła II w połączeniu z jego autorytetem moralnym w polskim społeczeństwie dobrze ilustrują tezę o centralnym znaczeniu, zapewne nie zawsze i nie do końca uświadamianym w skali społecznej, personalizmu jako podejścia aksjologicznego do regulacji statusu prawnego jednostki w polskiej Konstytucji. Trudno sobie wyobrazić alternatywę w tym zakresie, która mogłaby zintegrować społeczeństwo wokół konstytucyjnej karty praw. Zapewne nie powinny być nią ani postmodernistyczna aksjologiczna abdykacja na rzecz traktowania praw jednostki jako regulacji o czysto pozytywistycznym rodowodzie, ani jakaś wersja nacjonalistycznej wizji relacji pomiędzy jednostką a państwem.

\subsection{Kryterium zgodności z międzynarodowymi standardami praw człowieka}

W dyskursie nad konstytucyjna karta praw standardy międzynarodowe były jedna z podstawowych inspiracji. Nie chodziło tylko o ich wprowadzenie do krajowego porządku prawnego, ale także o tożsamość polskiego społeczeństwa. Przyjęcie bowiem tych standardów za punkt odniesienia polskiego porządku prawnego potwierdzało uznanie przyrodzonej godności ludzkiej za źródło praw człowieka, co znalazło później swój wyraz w art. 30 Konstytucji RP ${ }^{30}$. Jednakże w poczatkach transformacji miały one jeszcze inną funkcję. Ich inkorporacja do prawa wewnętrznego była drogą do Rady Europy, a przystąpienie do niej oznaczało nabycie „certyfikatu szlachectwa” pozwalającego na uczestnictwie w klubie, który przez dziesięciolecia wydawał się niedościgłym marzeniem. Również dlatego w przypadku sporów co do kształtu poszczególnych postanowień proponowanej konstytucyjnej karty praw powołanie się na potrzebę zgodności ze standardami międzynarodowymi miało niezwykła siłę perswazyjna. Na poziomie konstytucyjnym wymóg zgodności ze standardami międzynarodowymi został w ostateczności zasadniczo wzmocniony przez przyjęcie jednolitego systemu źródeł prawa powszechnie obowiązującego, który obejmuje m.in. traktaty międzynarodowe dotyczące praw człowieka, korzystające z pierwszeństwa, jeżeli nie da się z nimi pogodzić przepisów ustawowych ${ }^{31}$.

Czy dzisiaj kryterium zgodności z międzynarodowymi standardami praw człowieka ma nadal tę samą siłę? Pytanie niebagatelne. Wielu nadal uznaje, że standardy te chronia to, co ma znaczenie fundamentalne dla życia jednostki i społeczeństwa, że ich inkorporacja z jednej strony, a z drugiej - dostęp do działających na ich podstawie międzynarodowych instytucji i procedur ochronnych maja istotne znaczenie dla kompletności i efektywności systemu ochrony jednostki. Widoczna jest jednak także myśl, niemal nieobecna w początkach transformacji, że jeśli uniwersalne lub regionalne standardy sa odczuwane jako uciskajacy gorset, to lepiej ich nie przyjmować lub ewentualnie wyzwolić się z nich. Jednym z przykładów takiego myślenia jest zapewne Protokół polsko-brytyjski do Karty praw podstawowych ${ }^{32}$. Wprawdzie Anna Wyrozumska podkreśla, że

${ }^{30}$ Por. Preambuła i art. 1 Powszechnej deklaracji praw człowieka.

${ }^{31}$ Art. 91 ust. 2 Konstytucji RP.

${ }^{32}$ Protokół (nr 30) w sprawie stosowania Karty praw podstawowych Unii Europejskiej do Polski i Zjednoczonego Królestwa. M. Wyrzykowski, Awantura o Lizbonę, w: Z. Kędzia, A. Rost (red.), Wspótczesne wyzwania wobec praw człowieka w świetle polskiego prawa konstytucyjnego, Poznań 2009. 
celem Protokołu nie jest wyłączenie działania Karty w stosunku do Polski i Zjednoczonego Królestwa ${ }^{33}$, lecz jest nim sprecyzowanie warunków jej stosowania, ale w praktyce skutkiem Protokołu jest osłabienie wpływu zawartych w nim standardów na sytuację osób pozostających pod jurysdykcją państwa polskiego.

Czy ma to jednak oznaczać, że znaczenie omawianego tu kryterium konstruowania, interpretacji i ewentualnych poprawek do konstytucyjnej karty praw może zostać zakwestionowane? Oczywiście nie, jeśli uznajemy, że wartości chronione przez prawa człowieka mają fundamentalne znaczenie dla jednostki i państwa. Oczywiście nie, jeśli nie chcemy złamać zasady pacta sunt servanda. Oczywiście nie, jeśli nie pragniemy się pogrążyć w izolacji międzynarodowej, którą trudno byłoby dookreślić jako „splendid”.

Można przyjąć, że u zarania jej obowiązywania konstytucyjna karta praw co do zasady była zgodna z międzynarodowymi standardami praw człowieka. Z dzisiejszej perspektywy ocena tej zgodności wymagałaby analizy na dwóch poziomach. Pierwszy jest wyznaczony przez percepcję zobowiązań międzynarodowych. Drugi jest określony przez rozwój międzynarodowych standardów, do którego doszło w ciagu ostatnich dwudziestu lat.

Ponieważ ramy tego opracowania nie pozwalaja na przeprowadzenie takiej analizy, uzasadnione wydaje się poczynienie tylko kilku ogólnych spostrzeżeń. Co do pierwszej kwestii wieloletnie traktowanie przez ustawodawcę standardów międzynarodowych jako kryterium krajowej legislacji, kontrolny i interpretacyjny wpływ TK, a także wykonywanie dyrektyw unijnych przyczyniły się do tego, że konstytucyjna karta praw także w procesie implementacji zasadniczo zachowała walor zgodności ze standardami międzynarodowymi. Druga kwestia: czy ewolucja standardów międzynarodowych wskutek zmian w prawie traktatowym, przez orzecznictwo międzynarodowe, czy wreszcie przez rozwój tzw. miękkiego prawa międzynarodowego w dziedzinie praw człowieka nie ukazuje pewnych braków w konstytucyjnej karcie praw, które nie występowały lub nie były wystarczająco widoczne przed dwoma dekadami? Tutaj można wskazać m.in. na problemy, które wiążą się z narastającymi wyzwaniami dla jednostki płynaccymi z efektów postępu naukowego i technologicznego (np. badania i ingerencja w ludzki genom; dostęp i ramy korzystania z Internetu; posługiwanie się big data i autonomia oraz godność człowieka, a także zagrożenie manipulacja procesami demokratycznymi); zapobieganie wykluczeniu społecznemu i marginalizacji; rozpoznanie znaczenia horyzontalnego działania standardów praw człowieka (np. w odniesieniu do odpowiedzialności biznesu); czy wreszcie na odzwierciedlenie w standardach praw człowieka ewolucji stanowisk w kwestiach kulturowych (np. ochrona osób pozostających w związkach partnerskich i ochrona przed dyskryminacja ze względu na orientację seksualna).

${ }^{33}$ A. Wyrozumska, Znaczenie prawne zmiany statusu Karty Praw Podstawowych Unii Europejskiej w Traktacie Lizbońskim oraz Protokołu polsko-brytyjskiego, „Przegląd Sejmowy” 16, 2008, nr 2(85), s. 25 i n.; por. też Preambuła zd. 9 i 10; por też wyrok Wielkiej Izby TSUE z 21 grudnia 2011 r., Joined Cases C-411/10 and C-493/10, nr 119; <http://eur-lex.europa.eu/LexUriServ/LexUriServ.do?uri=CELEX:62010CJ0411:EN:HTML>, a także M. Wyrzykowski, op. cit., s. 257 i n.; K. Szymański, Kompetencje Unii jak plama oleju, „Rzeczpospolita” z 3 lipca 2007; M. Księżniakiewicz, Stosowanie Karty Praw Podstawowych Unii Europejskiej: Protokót brytyjski i Sprawozdania ze stosowania KPP UE, „Rocznik Integracji Europejskiej” 2012, nr 6, s. 333 i n. 
Jeszcze jedna kwestia wymaga zasygnalizowania w tym kontekście. Czy wskutek radykalizacji postaw w odniesieniu do tożsamości narodowej i kulturowej we współczesnych społeczeństwach, często prowokowanej lub podsycanej przez z jednej strony rozwarstwienie społeczne i w konsekwencji wykluczenie znacznych grup, a z drugiej - przez zarządzanie populistycznymi emocjami ze strony rozmaitych sił politycznych, nie następuje erozja znaczenia standardów międzynarodowych w odbiorze społecznym? Odpowiedź na to pytanie wymagałaby pogłębionych studiów. Można jednak odnieść wrażenie, że gdyby ta erozja nie postępowała, trudniej byłoby kolejnym rządom demonstrować postawę, nazwijmy to „obniżonej gotowości” do przyjmowania zobowiązań międzynarodowych w dziedzinie praw człowieka. Dla ilustracji można wskazać w tym kontekście na niektóre konwencje czekające od wielu lat na ratyfikację, wyraźną w ostatnich latach niechęć do akceptowania międzynarodowych procedur skargowych bądź wspomniany już Protokół polsko-brytyjski.

\subsection{Kryterium uniwersalności treści}

W pracach nad konstytucją w okresie transformacji ustrojowej zgłaszane były, zwłaszcza w początkowej fazie, wątpliwości, czy ująć w konstytucji prawa o charakterze socjalnym, czy też ograniczyć się tylko do praw osobistych i politycznych. Były w tym podejściu ślady utrzymujących się zwłaszcza w doktrynie i dyplomacji anglosaskiej poglądów, które odmawiają międzynarodowym standardom praw socjalnych charakteru praw człowieka. Była pewnie też chęć odcięcia się od wszystkiego, co chociażby ze względu na brzmienie kojarzyło się z poprzednim ustrojem. Konstytucja trafnie stanęła na gruncie zasady uniwersalności treściowej lub - jak to się niekiedy określa - holistycznego zakresu prawa człowieka, która została ostatecznie zaakceptowana podczas II Światowej Konferencji Praw Człowieka. W jej akcie końcowym wyraźnie podkreślono, że wszystkie kategorie praw są w równym stopniu doniosłe i, co więcej, są współzależne ${ }^{34}$. Konstytucyjna karta wyraźnie obejmuje wszystkie kategorie praw, poświęcając im kolejne tytuły, aczkolwiek spełniając kryterium jurydyczności, dostosowuje formę regulacji do swoistości materii.

Inna rzecz, że nurt traktowania praw socjalnych jako praw niższej kategorii jest nadal obecny w naszym życiu publicznym. Oficjalne stanowisko rządu prezentowane w oenzetowskich organach traktatowych praw człowieka głosi, że prawa socjalne w traktatach ratyfikowanych przez Polskę, które - mimo że zgodnie z Konstytucją przeważają nad polskimi ustawami w razie konfliktu nie mają charakteru normatywnego, różnią się bowiem swoją naturą od praw osobistych i politycznych. Te ostatnie z kolei podlegają bezpośredniemu stosowaniu w polskim porządku prawnym ${ }^{35}$. Powoływane jest przy tym stanowisko sądów, które - zdaniem rządu - „odwołują się do Międzynarodowego Paktu Praw Gospodarczych, Socjalnych i Kulturalnych jako do zbioru wytycznych [!]

${ }^{34}$ Wiedeńska Deklaracja i Program Działania, cz. I, § 5.

${ }_{35}$ Por. Comments by the Government of Poland on the concluding observations - UN Doc. E/C.12/POL/CO/5, §§ 1-6 (dokument ten został powołany w ostatnim sprawozdaniu Polski [E/C.12/POL/6 §§ 2-4 z 2016 r.], ale odnosił się do Obserwacji Końcowych sformułowanych w poprzednim cyklu sprawozdawczym). 
używanych w interpretacji krajowego porządku prawnego" ${ }^{36}$. Ta niefortunna - sprzeczna bowiem z wykładnią Paktu dokonaną przez powołany do tego Komitet Praw Gospodarczych, Socjalnych i Kulturalnych ${ }^{37}$, a w istocie deprecjonująca rangę prawną dyskutowanych standardów - interpretacja znajduje $\mathrm{w}$ sensie intencjonalnym potwierdzenie w stanowisku politycznym władz polskich w układzie, jak można to określić, ponadformacyjnym. Wyraża się ono w braku ratyfikacji Zrewidowanej europejskiej karty socjalnej ${ }^{38}$, braku ratyfikacji procedur skargowych odnoszacych się do praw socjalnych ustanowionych zarówno w ramach Rady Europy, jak i ONZ, a wreszcie we współautorstwie Protokołu polsko-brytyjskiego, który w zasadniczej mierze odnosi się do tytułu IV Karty praw podstawowych UE poświęconego prawom socjalnym.

Te fakty i oceny nie dowodza jednak tezy, że konstytucyjna karta praw nie spełnia kryterium uniwersalności. Aczkolwiek, aby skutecznie przeciwdziałać deprecjonowaniu znaczenia praw socjalnych, byłoby celowe przy okazji ewentualnej nowelizacji Konstytucji rozważenie rezygnacji z zastrzeżenia wyrażonego w jej art. 81, który stanowi, że „Praw określonych w art. 65 ust. 4 i 5 , art. 66 , art. 69 , art. 71 i art. 74-76 można dochodzić w granicach określonych w ustawie". Istotne znaczenie miałaby też zmiana w oficjalnym stosunku władz publicznych do tych praw. To jest jednak raczej sprawa wyborców, żeby ocenić, czy polityka organów państwa jest nie tylko zgodna, lecz także spójna z Konstytucją i zobowiązaniami międzynarodowymi przyjętymi przez Polskę. Podobnie ważne byłoby, aby doszło do odpowiednich zmian w linii orzeczniczej sądów i jednoznacznego uznania, że międzynarodowe standardy praw socjalnych ustanawiaja prawa jednostki, które mogą być stosowane mutatis mutandis $\mathrm{w}$ ramach krajowej jurysdykcji ${ }^{39}$.

\subsection{Kryterium jurydyczności}

Studiując dzisiaj kartę praw ujętą w Konstytucji RP, bez trudu można dostrzec determinację piszących ustawę zasadnicza, aby zapewnić jej walory instrumentu regulacyjnego, a nie poprzestać na zredagowaniu manifestu

${ }^{36}$ Replies of Poland to the List of issues [in relation to the sixth periodic report of Poland], UN Doc. E/C.12/POL/Q/6/Add.1, § 3 .

${ }^{37}$ Por. General comment No 9: The domestic application of the Covenant, UN Doc. E/C.12/1998/24, § 5-7; Committee on Economic, Social and Cultural Rights. Concluding observations on the sixth periodic report of Poland, UN Doc. E/C.12/POL/CO/6 (2016 r.), § 5.

38 Już 13 lat temu Ministerstwo Pracy i Polityki Społecznej zamieściło na swojej stronie internetowej komunikat o podpisaniu (ale nie ratyfikacji) przez Polskę Zrewidowanej karty socjalnej w 2005 r. i jednocześnie poinformowało, że „W związku z wynikami analizy ustawodawstwa polskiego z postanowieniami Karty oraz możliwymi konsekwencjami ekonomicznymi i społecznymi ich usunięcia, przewiduje się w 2006 roku podjęcie systemowych prac w kierunku ratyfikowania dokumentu”. Niestety ta zapowiedź nie przyniosła ostatecznego rezultatu.

${ }^{39}$ Wypada przypomnieć orzeczenia, na których opiera się stanowisko rządu wobec międzynarodowych standardów praw socjalnych: SN w orzeczeniu II UKN 374/99 z 8 lutego 2000 r. stwierdził, że Międzynarodowy pakt praw gospodarczych, socjalnych i kulturalnych nie wskazuje na żadne jednolite zasady, które miałyby zostać zastosowane przez państwa w odniesieniu do Paktu[?], i w konsekwencji doszedł do wniosku, że implementacja Paktu jest sprawą krajowej legislacji. Podobnie NSA w orzeczeniu w sprawie I OSK 8/06 z 16 maja 2006 r. 
programowego. Stąd bierze się jej wysoki, jak na akt konstytucyjny, poziom jurydyczności, który wyraża się zarówno w precyzji sformułowań i troskliwym doborze formy unormowań, jak i w ustanowieniu procedur dochodzenia praw. Nadal mam w pamięci dyskusje w Sejmie z ekspertami pochodzacymi z krajów anglosaskich, którzy dziwili się, że zarówno posłowie, jak i rzeczoznawcy krajowi starali się nadać postanowieniom karty praw jak najdokładniejszą treść, skoro „w końcu sędzia i tak sobie da radę, a nie powinien być zbyt mocno skrępowany jednoznacznymi i szczegółowymi przepisami”. Konstytucja stoi jednak mocno na gruncie kontynentalnego systemu prawa. Rozróżnia, może nie zawsze konsekwentnie ${ }^{40}$, pomiędzy uregulowaniami w formie zasad prawa, praw podmiotowych oraz norm programowych. Sprawia to, że konstytucyjna karta praw z 1997 r. z redakcyjnego punktu widzenia spełnia omawiane tu kryterium.

Gwarancjom praw jednostki w świetle Konstytucji RP jest poświęcone inne opracowanie w tym tomie. Dlatego w tym miejscu należy jedynie podkreślić, że zasadniczo zostały one skonstruowane według modelu, który odpowiada rozwiązaniom przyjmowanym we współczesnych konstytucjach. Oprócz gwarancji o charakterze systemowym (ustanowienie ustroju demokratycznego, zasada podziału władz wraz z zasadą niezależności sądów od innych władz, zwłaszcza rządu, i niezawisłości sędziów, sądowa kontrola konstytucyjności prawa) obejmuja one gwarancje instytucjonalne i proceduralne, a w tym: prawo do sądu, prawo do odwołania instancyjnego (na drodze administracyjnej i sądowej), prawo do skargi konstytucyjnej i prawo do odszkodowania za szkody, które podmiotowi praw zostały wyrządzone przez niezgodne z prawem działanie organu władzy publicznej, a także wniosek o pomoc do Rzecznika Praw Obywatelskich i odpowiednio do Rzecznika Praw Dziecka.

Nie jest to jednak kompletny system ochrony. Jak pokazuje bowiem praktyka konstytucyjna, w sytuacjach, w których decyzję ostateczną podejmuje Prezydent RP w ramach swoich prerogatyw, podmiot praw jest faktycznie pozbawiony drogi odwoławczej, w tym sądowej, ich dochodzenia wbrew art. 77 ust. 2 Konstytucji ${ }^{41}$.

Osobną kwestia jest funkcjonowanie i skuteczność gwarancji praw. Biorąc pod uwagę sam tekst Konstytucji, nie wydaje się, żeby wymagał on zasadniczych zmian lub uzupełnień, poza - być może - uregulowaniem wskazanego problemu ostateczności decyzji Prezydenta RP i ewentualnie rozpatrzeniem możliwości wprowadzenia do polskiego porządku prawnego zyskującej w świecie na popularności skargi sądowej w interesie publicznym (public interest litigation). Trudno byłoby natomiast wprowadzać konstytucyjny zakaz dysfunkcjonalnych kroków ustawodawczych w omawianej materii, jako że wynika on w sposób oczywisty z zasady spójności prawa z konstytucją. Należy mieć nadzieję, że polski parlament będzie się kierował w przyszłości obserwacją sę-

${ }^{40} \mathrm{~Np}$. użycie w art. 81 Konstytucji określenia prawa w stosunku do niektórych przepisów o charakterze programowym.

${ }^{41}$ Osobnej analizy z punktu widzenia zupełności regulacji konstytucyjnej wymagałoby orzecznictwo TK i NSA odnoszące się do sądowej kontroli aktów Prezydenta wydawanych w ramach jego prerogatyw ustanowionych w art. 144 ust. 3 Konstytucji. 
dziego Frankfurtera, według którego „Historia wolności była w dużym stopniu historia respektowania gwarancji proceduralnych" ${ }^{2}$.

\section{Przykłady ewentualnych zmian w tekście Konstytucji}

Z dotychczasowych wywodów wynika zapewne wniosek, że konstytucyjna karta praw nie wymaga rewizji lub zastapienia z powodów zasadniczych. Ogólnie rzecz biorac, stanowi ona przykład nowoczesnej regulacji sytuacji prawnej jednostki, zgodnej z wymogami współczesnego konstytucjonalizmu. Ta generalna ocena nie oznacza jednak braku celowości rozważań nad możliwościa bądź potrzebą optymalizacji szczegółowych rozwiązań, które mogłyby zostać dokonane w ramach nowelizacji konstytucji, gdy ta okaże się niezbędna. Ramy tego opracowania pozwalaja jedynie na zasygnalizowanie nielicznych przykładów w tej mierze na zasadach ilustracji.

\subsection{Wskazanie w Konstytucji tzw. zakazanych powodów dyskryminacji}

Konstytucja RP jest wyjątkowa, jeśli chodzi o sposób regulacji zakazu dyskryminacji. Inaczej niz traktaty z dziedziny praw człowieka i wiele innych konstytucji, polska ustawa zasadnicza nie definiuje zakazanych powodów dyskryminacji. Źródłem tego rozwiązania był fakt, że regulacje międzynarodowe i krajowe wskazujące, z jakich przyczyn nie można wprowadzać zróżnicowania praw jednostki, czynia to jedynie na zasadzie przykładu. Potwierdza to dodawana często na końcu właściwych przepisów fraza: „i z jakichkolwiek innych przyczyn", a także orzecznictwo krajowe i międzynarodowe. W tej sytuacji, skoro dyskryminacja powinna być zakazana z wszelakich przyczyn, ustrojodawca postanowił nie wymieniać żadnych z nich i uniknąć w ten sposób sugestii, że te przyczyny, które zostały expressis verbis wskazane, sa niejako bardziej zakazane niż inne. W dyskusjach na temat dyskryminacji (np. ze względu na orientację seksualna) pojawiały się jednak argumenty wskazujące, że Konstytucja takiej dyskryminacji wyraźnie nie zabrania. Jeśli obecna artykulacja art. 32 ust. 2 miałaby podpierać dyskryminację w jakimkolwiek przypadku (tzw. dyskryminacja wyrównawcza pozostaje poza prowadzonymi tutaj rozważaniami), to być może należy zastanowić się, czy nie lepiej byłoby jednak zamieścić w nim otwarta, ale możliwie pełną listę zakazanych powodów dyskryminacji.

\subsection{Uznanie praw osób z niepełnosprawnościami}

Konstytucja RP jest niezwykle wstrzemięźliwa w tym zakresie. Nie uznaje szczególnych praw tej kategorii osób, a ich ochronę ujmuje jedynie, i to w bar-

${ }^{42}$ US Case Law, U.S. Supreme Court, McNabb v. United States, 318 U.S. 332(1943), s. 308. 
dzo ogólny sposób, w kategoriach obowiązku władz publicznych ${ }^{43}$. Należy postulować, aby w przyszłości doszło do konstytucyjnego umocowania osób z niepełnosprawnościami jako podmiotów praw wywodzących się z ogólnego prawa do niezależnego, samodzielnego i aktywnego życia ${ }^{44}$. Wymaga podkreślenia, że dla wzmocnienia ochrony $\mathrm{w}$ tym zakresie nie wystarczy ewentualne wpisanie niepełnosprawności jako jednego z zakazanych powodów dyskryminacji.

\subsection{Uniwersalność przedmiotowa konstytucyjnych praw}

W świetle prowadzonych rozważań na temat równego statusu w Konstytucji praw osobistych i politycznych oraz praw socjalnych rozważenia wymaga rezygnacja z wyłączenia bezpośredniego stosowania przepisów dotyczących tych praw, które wymienia art. 81 ustawy zasadniczej. Dotyczą one czterech praw, a mianowicie prawa do bezpiecznych i higienicznych warunków pracy, do dni wolnych od pracy, do informacji o stanie i ochronie środowiska i prawa matki przed i po urodzeniu dziecka do szczególnej pomocy ze strony władz publicznych. Jak już wspomniano, z systemowej wykładni Konstytucji wynika, że ustrojodawca celowo rozróżniał między językiem praw i normami programowymi, które nie mogą stanowić samodzielnej podstawy roszczenia. Konsekwentne stosowanie tego założenia zdaje się, że pozbawia art. 81 uzasadnienia.

\subsection{Związanie biznesu prawami czlowieka}

Jak wiadomo, kwestia ta nabiera ostatnio szybko znaczenia zarówno na poziomie międzynarodowym, jak i krajowym. Konstytucja nie wypowiada się w tej materii. Hipotetycznie rozwiązaniem mogłoby być zaakceptowanie przez ustawę zasadniczą koncepcji horyzontalnego działania konstytucyjnych praw jednostki. Krok taki miałby jednak bardzo poważne konsekwencje dla niepaństwowych podmiotów, w tym zarówno osób fizycznych, jak i prawnych. Oznaczałby bowiem możliwość interpretacji obowiązków ciążących na tych podmiotach z praw jednostki. Dlatego kwestia ta wymaga niezwykle troskliwej analizy i dyskusji poprzedzajacej kroki prawodawcze. Bezpieczniejsze wydają się w tej sytuacji konkretne regulacje dotyczące biznesu. Mogłyby one dotyczyć nie tylko obowiązku przedsiębiorstw, w zakresie ich działalności, do respektowania praw jednostki uregulowanych w Konstytucji i ustawach, lecz także obowiązku stosowania zasady należytej staranności (due diligence) dla unikania negatywnego oddziaływania na prawa człowieka ${ }^{45}$. Wobec coraz

43 Por. art. 68 i 69 Konstytucji RP.

${ }_{44}$ Por. Karta praw osób niepełnosprawnych z dnia 1 sierpnia 1997 r., Uchwała Sejmu RP z dnia 1 sierpnia 1997 r., M.P. 1997, Nr 50 poz. 475.

${ }^{45}$ Por. Committee on Economic, Social and Cultural Rights, General comment No. 24 (2017) on State obligations under the International Covenant on Economic, Social and Cultural Rights in the context of business activities, UN Doc. E/C.12/GC/24, §§ 15-17, 31-33, 50; Polski Instytut Praw Człowieka i Biznesu, Fundacja im. Friedricha Eberta, NSZZ Solidarność, red. Beata Faracik, Wytyczne dotyczace biznesu i praw człowieka. Wdrażanie dokumentu ramowego ONZ: „Chronić, Szanować i Naprawiać", Częstochowa 2014, s. 31-37; źródło oficjalne: UN Doc. A/HRC/17/31, $\S \S 17-21$. 
większego zaangażowania polskich przedsiębiorstw za granica, celowe byłoby też uwzględnienie eksterytorialnego wymiaru obowiązków państwa w dziedzinie praw człowieka ${ }^{46}$.

\subsection{Zasada non-refoulement}

Ogólność regulacji konstytucyjnej dotyczącej prawa azylu ${ }^{47}$ jest zapewne pochodna raczej ograniczonej skali problemu w czasie przygotowywania ustawy zasadniczej. Majac jednak na uwadze doświadczenia z polskich przejść granicznych, a także kontrowersje wokół polskiej polityki w tym zakresie, należy zastanowić się, czy nie jest potrzebne wyraźne sformułowanie w Konstytucji zasady non-refoulement (zakaz wydalania lub zawracania), przewidzianej Konwencją dotyczącą statusu uchodźców ${ }^{48}$.

\subsection{Prawa cudzoziemców}

Konstytucja wyraźnie postanawia, że każda osoba znajdująca się pod jurysdykcją Rzeczypospolitej Polskiej korzysta z wolności i praw zapewnionych $\mathrm{w}$ Konstytucji ${ }^{49}$. To postanowienie w pełni koresponduje z zasadami ochrony praw człowieka. Osłabia je jednak towarzyszący mu przepis, zgodnie z którym ustawodawca zwykły określa wyjątki od tej zasady ${ }^{50}$. Wydaje się, że bardziej konsekwentne byłoby sformułowanie w samej Konstytucji chociażby zasad i dopuszczalnego zakresu stanowienia takich wyjątków. To jest kolejny przykład postanowień, które mogłyby zostać rozpatrzone w ramach ewentualnej nowelizacji ustawy zasadniczej.

prof. dr hab. Zdzistaw Kędzia

Wyższa Szkoła Bankowa we Wroctawiu

oraz Uniwersytet im. Adama Mickiewicza w Poznaniu

zdzislaw.kedzia@wsb.wroclaw.pl

DO WE NEED TO REVISE THE CONSTITUTIONAL CHARTER OF RIGHTS?

$$
\text { Summary }
$$

The article seeks to answer the question whether it is necessary to revise the charter of rights of an individual included in the Constitution of the Republic of Poland of 1997. The starting point is the reflection on the topicality of the Basic Law from the perspective of 20 years of its applicability. The conclusion is that the Constitution meets the criteria of modern constitutionalism upon which the systems of democratic states are based. The reform consisting in a thorough revision of the existing Constitution or in replacing it with a new basic law would have to be justified by

${ }^{46}$ Por. General comment No. 24 (2017), op. cit., zwłaszcza §§ 25-37.

${ }_{47}$ Art. 56 Konstytucji RP.

48 Art. 33 ust. 1 Konwencji z 28 lipca 1951 r.; por. też art. 3 Konwencji w sprawie zakazu stosowania tortur oraz innego okrutnego, nieludzkiego lub poniżającego traktowania albo karania z dnia 10 grudnia $1984 \mathrm{r}$.

49 Art. 37 ust. 1 Konstytucji RP.

${ }^{50}$ Ibidem, ust. 2. 
the fulfilment of the 'constitutional moment' conditions, in line with Bruce Ackerman's understanding of the term. The discussion devoted to the constitutional charter of rights focuses on the assessment of how the fundamental rights charter fulfils the criteria which guided its drafting, namely: the adequacy to the assessment of the relationship between the individual and the community that prevails in society; the compliance with international human rights standards; the universality of content; the jurisprudence. They lead to the conclusion that the charter of rights contained in the Constitution is an example of a modern regulation of the legal situation of an individual, consistent with the requirements of contemporary constitutionalism. However, this general assessment does not mean that it is pointless to consider the possibility or the need to refine the detailed solutions, or supplement the list charter, that could be made within the framework of the revision of the Constitution when this proves necessary. This thesis is illustrated with selected examples. 